\title{
Studi Induksi Mutasi Genetik Pisang Barangan Melalui Aplikasi Iradiasi Sinar Gamma Secara In Vitro
}

\section{(The Study Genetic Mutation Induction of Pisang Barangan Through in Vitro Gamma Iradiation Applications)}

\author{
Zarmiyeni $^{1)}$ dan Ishak ${ }^{2)}$ \\ ${ }^{1)}$ Program Studi Agroteknologi, Sekolah Tinggi Ilmu Pertanian Amuntai \\ zarmiyenilg@yahoo.co.id \\ ${ }^{2)}$ Pusat Aplikasi Teknologi Isotop dan Radiasi-BATAN \\ Kotak Pos 7002 JKSL, Jakarta 12070,
}

\begin{abstract}
ABSTRAK
Studi mutasi genetik yang menginduksi pisang Barangan dengan iradiasi sinar gamma secara in vitro bertujuan untuk mempelajari dan mengevaluasi dosis iradiasi sinar gamma dalam meningkatkan berbagai planet genetik pisang barangan yang regenerasi ujung pucuk dengan arah menjadi layu. Lebih 20 tip menembak masing-masing dalam iradiasi sebesar 10 Gy dan 20 Gy, dan dihitung sebagai berbeda. Planet dalam regenerasi dalam media MS mengandung $3 \mathrm{mg} / 1$ BAP dan 0,5 $\mathrm{mg} / 1$ IAA. Akurasi hasil menunjukkan persentase tunas tumbuh setelah iradiasi Gy 80\% iradiasi, 20 Gy 75\% iradiasi dan 85\% countrol. Dosis iradiasi mempengaruhi jumlah produksi propagoula. Peningkatan dosis iradiasi dosis untuk meningkatkan jumlah produksi propagoula. Produk propagoula akurasi ini adalah 5 jenis yaitu 15 planet, tunas, tunas, kelompok tunas dan nodul
\end{abstract}

Kata kunci: Gamma, ray, propagoula, pisang, barangan.

\section{ABSTRACT}

The study of mutation genetic induct Barangan banana by irradiation gamma ray according in vitro aimed to learning and evaluate dose irradiation gamma ray in to increase various of genetic planet barangan banana that regeneration of shoot tip by direction to withered ache. More 20 shoot tip each in irradiation by 10 Gy and $20 \mathrm{~Gy}$, and countrat as different. Planet in to regeneration in MS media to contain $3 \mathrm{mg} / 1 \mathrm{BAP}$ and 0,5 mg/ I IAA. Result accuration showed percentation bud was grow after irradiation Gy $80 \%$ Irradiation, 20 Gy 75\% Irradiation and 85\% countrol. Irradiation dose to affect sum propagoula produce. The increase of irradiation dose tedence to increase sum propagoula produce. The propagoula produce of this accuration was 5 sort that 15 planet, shoot, bud, bud group and nodule.

Keywords: Gamma, ray, propagoula, banana, barangan.

\section{PENDAHULUAN}

Pemuliaan tanaman pisang pada saat ini dimungkinkan melalui pemuliaan mutasi dan metode bioteknologi (Suprasanna et al., 2008). Pemuliaan mutasi didasarkan kepada keragaman genetik. Melalui teknik in vitro yang dikombinasikan dengan teknik induksi mutasi (disebut mutagenesis in vitro) dapat menghasilkan mutan baru yang memiliki tingkat keragaman genetik yang bervariasi. Menurut Roux (2004); Mak et al. (2000) induksi keragaman dengan perlakuan mutagenesis dan perbanyakan tanaman secara in vitro merupakan pendekatan yang efektif untuk meningkatkan keragaman genetik tanaman yang diperbanyak secara vegetatif atau klonal.

Tanaman pisang komersial termasuk pisang barangan diperbanyak secara vegetatif sehingga mempunyai keragaman genetik rendah karena tidak terjadi hibridisasi seksual (Roux, 2004). Keragaman genetik tanaman dengan karakteristik seperti Musa spp. dapat ditingkatkan melalui induksi dengan mutagenesis.

Induksi mutasi dapat menjadi metode yang baik dalam pemuliaan tanaman karena dapat menghasilkan ratusan varietas baru yang berasal dari bermacam-macam spesies tanaman (Micke et al., 1987). Induksi mampu merubah satu atau sedikit sifat tanpa merubah 
karakter khusus dari kultivar (Mak et al., 2000). Kombinasi teknik in vitro dengan induksi mutasi dapat memperbaiki varietasn tanaman lokal (Ahloowalia et al., 1996). Keuntungan lain dari induksi mutasi secara in vitro adalah dapat menghasilkan planlet dalam skala besar, dapat ditangani dengan mudah dan cepat, sehingga seleksi sifat tertentu dapat dilakukan dalam keadaan lingkungan yang sama.

Proses induksi mutasi dapat dipercepat dengan menggunakan mutagen. Mutagen fisika, seperti iradiasi sinar gamma dapat merubah konstitusi genetik yang ada pada genom tanaman ke arah yang diinginkan dengan keragaman genetik yang lebih luas (Mak et al., 1996; Ishak, 2000). Penggunaan iradiasi sinar gamma pada tanaman pisang telah dilaporkan oleh Mak et al., (1996); Espino et al. (1992); Smith et al. (1990); Silayoi et al. (1986).

Hasil penelitian Micke, Donini and Maluszynzki (1987), Nagatomi (1996) dan Matsumoto et al. (2000a, 2000b) mendapatkan bahwa perlakuan iradiasi yang dikomb inasikan dengan seleksi in vitro memperbesar peluang untuk mendapatkan varietas yang tahan terhadap penyakit. Hasil penelitian Epp (1986) dan Smith et al. (1996) bahwa perlakuan iradiasi sinar gamma dan seleksi in vitro dapat menghasilkan pisang cavendish yang tahan terhadap penyakit layu Fusarium. Imelda et al. (1997) melaporkan bahwa iradiasi sinar gamma pada dosisi 200 rad dapat menghasilkan klon pisang raja sereh yang toleran terhadap Banana Bunchy Top Virus (BBTV).

Penelitian ini bertujuan untuk mempelajari dan mengevaluasi dosis iradiasi sinar gamma dalam meningkatkan keragaman genetik plantlet pisang barangan yang diregenerasikan dari shoot tip dengan arah tahan terhadap penyakit layu.

\section{BAHAN DAN METODE}

Penelitian ini dilaksanakan di Laboratorium Kultur Jaringan Pusat Penelitian dan Pengembangan Teknologi Isotop dan Radiasi (P3TIR) Badan Tenaga Nuklir Nasional (BATAN), Pasar Jumat, Jakarta dari bulan April 2005 - Maret 2006
Penelitian menggunakan Rancangan Acak Lengkap (RAL) satu faktor dengan 3 perlakuan. Perlakuan yang diuji merupakan dosis iradiasi sinar gamma (I) yaitu : $\mathrm{I}_{1}=$ tanpa iradiasi (kontrol), $\mathrm{I}_{2}=$ dosis iradiasi 10 Gy dan $\mathrm{I}_{3}=$ dosis iradiasi 20 Gy. Setiap perlakuan diulang 20 kali sehingga didapatkan 60 satuan percobaan.

\section{Persiapan eksplan}

Eksplan yang digunakan adalah shoot tip yang berasal dari hasil perbanyakan secara in vitro dan masih berada dalam botol dalam keadaan steril. Eksplan ini diperbanyak pada media perbanyakan sampai mencukupi untuk dilakukan iradiasi. Eksplan di dalam botol yang digunakan adalah yang berumur sekitar $3-4$ minggu dengan tinggi sekitar $5 \mathrm{~cm}$, yang didapatkan dari BBI Ragunan Jakarta.

\section{Media perbanyakan}

Media perbanyakan yaitu media dasar MS (Murashige dan Skoog, 1962) yang terdiri dari nutrisi makro dan mikro ditambahkan dengan $0,5 \mathrm{mg} / \mathrm{l}$ nicotinic acid, $0,5 \mathrm{mg} / \mathrm{l}$ pyrodoxin, $0,4 \mathrm{mg} / \mathrm{l}$ thiamine. $\mathrm{HCl}$, $0,2 \mathrm{mg} / \mathrm{l}$ glycine, $100 \mathrm{mg} / \mathrm{l}$ myoinositol, 3 $\mathrm{mg} / \mathrm{l}$ BAP, $0.5 \mathrm{mg} / \mathrm{l}$ IAA dan $30 \mathrm{~g}$ sukrosa. Media ini dipadatkan dengan menggunakan 8 $\mathrm{g} / \mathrm{l}$ agar, dan $\mathrm{pH}$ diatur 5,8 sebelum di autoklaf.

\section{Aplikasi iradiasi sinar gamma}

Tunas in vitro yang berumur 3 minggu di dalam botol di pilih yang mempunyai daun 3 lembar diiradiasi dengan sinar Gamma. Dosis iradiasi yang diberikan sesuai dengan perlakuan. Sinar gamma berasal dari Cobalt-60 $\left({ }^{60} \mathrm{Co}\right)$ dengan alat yang digunakan untuk meradiasi adalah Irradiator Gamma Cell 220. Setelah diiradiasi eksplan segera dipindahkan ke media perbanyakan yang baru, untuk mencegah terjadinya radikal bebas. Tunas hasil iradiasi ini diregenerasikan selama 1 bulan.

\section{Pengamatan}

Pengamatan dilakukan terhadap peubah : Persentase eksplan yang hidup setelah iradiasi sinar gamma (\%) dan jumlah propagula yang terbentuk. 


\section{HASIL DAN PEMBAHASAN}

Hasil analisis statistik menunjukkan bahwa pemberian dosis iradiasi sinar gamma Tabel 1. Persentase tunas yang hidup $(\%)$ setelah iradiasi sinar gamma pada umur 3 minggu setelah iradiasi

\begin{tabular}{cc}
\hline Dosis Iradiasi Sinar Gamma & Persentase Tunas Yang Hidup (\%) \\
\hline Kontrol & 85 \\
$10 \mathrm{~Gy}$ & 80 \\
$20 \mathrm{~Gy}$ & 75 \\
\hline
\end{tabular}

Ket : Angka-angka pada kolom yang sama berbeda tidak nyata menurut uji $\chi^{2}$ pada taraf nyata 5 $\%$.

Dari Tabel 1 terlihat ada kecenderungan penurunan persentase tunas yang hidup setelah iradiasi dengan peningkatan dosis iradiasi yang diberikan, namun hasil pengujian belum signifikan. Hal ini diduga disebabkan oleh dosis yang digunakan adalah dosis rendah. Hasil penelitian Mak et al (2004) mendapatkan bahwa dosis iradiasi yang digunakan untuk menginduksi pisang barangan adalah berkisar antara $20-60$ Gy. Menurut Wiryosimin (1995) bahwa dosis yang lebih tinggi akan menyebabkan sel mati atau mengalami perubahan sifat. Lebih lanjut Ratma (1988) menambahkan bahwa semakin tidak berpengaruh terhadap persentase tunas yang hidup setelah iradiasi. Rata-rata persentase tunas yang hidup setelah diiradiasi dengan sinar gamma disajikan pada Tabel 1.
diasi sinar gamma pada umur 3 minggu setelah Persentase Tunas Yang Hidup (\%) besar dosis iradiasi sinar gamma, makin besar pula kerusakan genetik maupun fisiologi yang ditimbulkan.

Tunas yang tidak diperlakukan dengan iradiasi sinar gamma (kontrol) menunjukkan persentase hidup yang tertinggi, yaitu $85 \%$. Perlakukan iradiasi dengan dosis 10 Gy cenderung menurunkan persentase tunas yang hidup menjadi $80 \%$. Dengan meningkatkan dosis iradiasi menjadi 20 Gy, maka persentase tunas yang hidup cenderung semakin menurun menjadi $75 \%$. Kondisi tunas yang hidup setelah diiradiasi dapat dilihat pada Gambar 1.

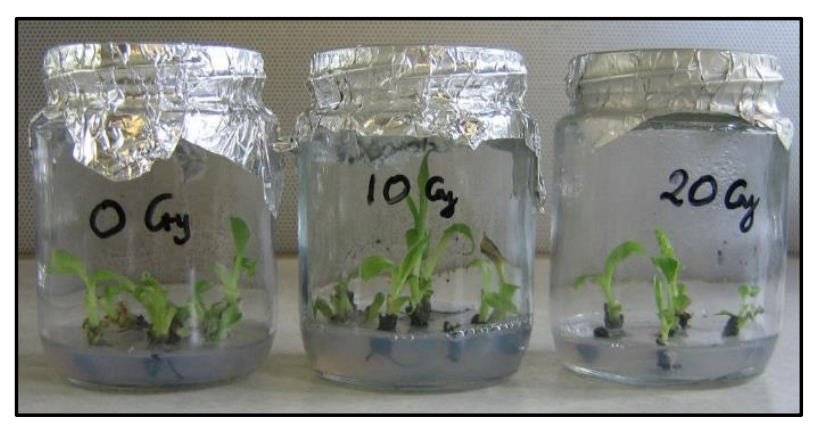

Gambar 1. Pertumbuhan tunas pisang setelah dilakukan iradiasi: 0 (kontrol), 10 Gy, dan 20 Gy

Radiasi gamma merupakan
gelombang elektromagnetik yang
memancarkan energi foton dan mempunyai
daya tembus yang sangat besar sekali
terhadap benda yang dilewatinya. Oleh sebab
itu apabila radiasi ini diperlakukan pada sel
tanaman mengakibatkan terjadinya
perubahan makro molekul DNA yang ada
dalam nuclear genom maupun pada DNA mitokondria di sitoplasma. Tahap kejadian mulai dari radiasi sampai perubahan yang terjadi pada sel adalah terjadinya proses fisika yaitu interaksi antara makro molekul DNA dengan foton dan dalam waktu bersamaan terjadi proses radiolisis yang menghasilkan eksitasi dan ionisasi. Kemudia proses kimia dimana hasil dari radiolisis air dan molekul lainnya akan merusak makro 
molekul dan kemudian terjadi restitusi kimia dan perbaikan. Selanjutnya terjadi proses biokimia dimana perbaikan makro molekul yang rusak dengan dikatalisis oleh enzim, sedangkan yang terakhir adalah proses biologi (Alpen, 1990).

\section{Jumlah propagula yang terbentuk}

Hasil pengamatan terhadap jumlah propagula yang terbentuk setelah induksi mutasi genetik pisang barangan melalui aplikasi iradiasi sinar gamma disajikan pada Tabel 2.

Tabel 2. Jumlah propagula yang terbentuk pada induksi mutasi genetik pisang barangan melalui aplikasi iradiasi sinar gamma

\begin{tabular}{cccccc}
\hline \multirow{2}{*}{$\begin{array}{c}\text { Tingkat Iradiasi } \\
\text { Sinar Gamma }\end{array}$} & Planlet & Pucuk & Tunas & $\begin{array}{c}\text { Kumpulan } \\
\text { Tunas }\end{array}$ & Nodul \\
\cline { 2 - 6 } & 0,4 & 0,8 & 0,5 & - & - \\
Kontrol & 0,6 & 0,1 & 2,0 & - & 0,1 \\
10 Gy & 0,2 & 0,8 & 2,0 & 0,3 & 0,1 \\
20 Gy & &
\end{tabular}

Ket : Angka-angka pada kolom yang sama berbeda tidak nyata menurut uji $\chi^{2}$ pada taraf nyata 5 $\%$.

Tabel 2 memperlihatkan bahwa dosis iradiasi yang diberikan menghasilkan propagula yang sangat bervariasi. Propagula yang terbentuk ada lima macam yaitu (1) planlet, (2) pucuk, (3) tunas, (4) kumpulan tunas dan (5) nodul. Kreteria planlet adalah propagula dengan daun yang telah membuka sempurna dan mempunyai akar. Pucuk merupakan propagula yang memiliki daun telah membuka sempurna namun tidak mempunyai akar. Tunas merupakan propagula dengan daun masih menggulung dan tidak mempunyai akar. Kumpulan tunas merupakan propagula yang terdiri dari beberapa tunas berukuran kecil dan sulit untuk dipisahkan. Sedangkan nodul merupakan propagula yang berbentuk bongkahan dengan warna putih atau hijau atau hitam.

Pada kontrol propagula yang dihasilkan adalah planlet, pucuk dan tunas. Pada perlakuan dosis iradiasi 10 Gy propagula yang terbentuk adalah planlet, pucuk, tunas dan nodul. Pada perlakuan dosis iradiasi 20 Gy propagula yang dihasilkan adalah planlet, tunas, pucuk, kumpulan tunas dan nodul. Peningkatan dosis iradiasi cendrung meningkatkan jumlah propagula yang terbentuk, terlihat pada Tabel 2 , pada kontrol jumlah propagula yang terbentuk adalah 1,7 , perlakuan dosis iradiasi 10 Gy 2,9 dan perlakuan dosis iradiasi 20 Gy meningkat menjadi 3,4.

Perlakuan iradiasi cendrung meningkatkan jumlah propagula yang terbentuk. Hal ini disebabkan dosis iradiasi yang digunakan dalam penelitian tergolong dosis yang rendah. Sebagaimana yang dikemukakan oleh IAEA (1985) bahwa radiasi dosis rendah memberikan efek stimulasi pada pertumbuhan tanaman. Sebaliknya menurut Bacq and Alexander (1966) dan Broertjes (1977) pada dosis iradiasi yang lebih besar akan menyebabkan terjadi hambatan yang besar pula sehingga tunas cenderung tidak terbentuk.

\section{KESIMPULAN}

Hasil penelitian menunjukkan bahwa persentase tunas yang hidup setelah iradiasi 10 Gy $80 \%$, iradiasi 20 Gy $75 \%$ dan kontrol $85 \%$. Semakin tinggi dosis iradiasi ada kecendrungan peningkatan jumlah propagula yang terbentuk. Ada 5 macam propagula yang dihasilkan dari penelitian ini yaitu planlet, pucuk, tunas, kumpulan tunas dan nodul. 


\section{DAFTAR PUSTAKA}

Ahloowalia, B. S. 1986. Limitations to the Use of Somaclonal Variation in Crop Improvement. In: Somaclonal Variation and Crop Improvement. J. Semal (Ed.). Martinus Nijhoff Publ. New York. p:15-27.

Alpen, E. L. 1990. Radiation Biophysic. Prentice - Hall International. London.

Bacq, A. M and P. Alexander. 1966. Fundamentalis of Radiobiology. New York

Broertjes, C. 1977. Induced mutations Techniques to Breeding Asexualy Propagated Plants. Manual on Mutation Breeding Technology. Vienna IAEA no. 119.

Epp. M. D. 1986. Somaclonal variation in bananas: A case study with Fusarium wilt of banana and plantain breeding strategies. Proc. of an Intern. Workshop held at Cairns Australia 13 -17 Oct. 1986. INIBAP/ACIAR Proc. No. $21: 140$ - 150.

Espino, R. R. C., S. H. Jamaluddin, B. Silayoi, and R. E. Nasution. 1992. Musa L. (edible cultivar). In : Plant Resources of South East Asia No. 2: Edible Fruits and Nuts. Verheij FWN, Coronel, RE (Ed.). Prosea Foundation. Bogor.

Herawati, T. dan R. Setiamihardja. 2000. Pemuliaan Tanaman Lanjutan. Padjadjaran Univ. Bandung.

IAEA. 1985. Mutation Breeding for Disease Resistance Using In Vitro Culture Techniques. IAEA. Vienna.

Imelda, M., Atmowidjojo, S., Dewina, P., Estiati, A., and Hartati, S. 1997. Perluasan keragaman genetik pisang melalui teknologi biak jaringan dan induksi mutasi untuk ketahanan terhadap virus bunchy top. Laporan akhir RUT I 1995/1996. Dalam: seri kumpulan abstrak riset unggulan terpadu no 1. Tjondronegoro, J.Djatin, R.N. Rahayu dan S. Iswanti (Eds). Kantor menteri negara riset dan teknologi. Proyek pengembangan dan peningkatan kemampuan teknologi-LIPI Jakarta. Hal 30

Ishak. 2000. Improvement of banana quality trought induced mutation. Paper Presented on Seminar of Methodology for Plant Mutation Breeding: Screening for Quality. Jakarta.

Mak, C., A. A. Mohamed, K. W. Liew, and Y. W. Ho. 1996. Double tray technique for the screening of fusarium wilt resistance in banana nursery plants. Malaysian Jour:Of Sci

Mak, C., Y. W. Ho, K. W. Liew, M. Azhar, J. M. Asif, dan A. A. Mohamed. 2000. In vitro manipulation and mutation breeding for the improvement of banana. Promusa 8 (2) : VI - VII

Mak, C., Y. W. Ho, K. W. Liew, M. Azhar, and J. M. Asif. 2004. Biotechnology and in vitro mutagenesis for banana improvement. In: Banana improvement:cellular, molecular biology, and induced mutations. S.Mohan Jain and Rony Swennen (eds.). Proceeding from meeting held September $24 \quad-\quad 28,2001$. http://www.scipub.net.

Matsumoto, K., M. L. Barbosa, and J. B. Teixeira. 2000a. In vitro selection for Fusarium wilt resistance in banana. 1. Resistance to culture filtrate of race 1 Fusarium oxysporum f.sp. cubense. Musarama 13: 19. Abstrac 6054.

Matsumoto, K., C. Souza, and M. L. Barbosa. 2000b. In vitro selection for Fusarium wilt resistance in banana. 
1. Co-culture technique to produce culture filtrate of race 1 Fusarium oxysporum f.sp. cubense. Musarama $13: 19$. Abstrac 6055.

Micke, A. and M. Maluszynski. 1987. Induced mutation for crop improvement - a review. Trop. Agric. Trinidad. 64 : 259 - 278.

Murashige, T. and F. Skoog. 1962. A revised medium for rapid growth and bioassay with tobacco tissue culture. Physiol. Plant 15 : 473 - 497.

Nagatomi, S. 1996. A new appoarch of radiation breeding toward improvement of disease resistance in crops. Proc. Seminar on Integrated Control on Main Disease of Industrial Crops. Bogor, 13 - 14 March 1996. RISMC-JICA. hlm 16 - 24.

Roux, N. S. 2004. Mutation induction in Musa-review. In: Banana Improvement ; Cellular, Molecular Biology and Induced Mutations. Jain SM and Swennen R (Eds.). Enfield : Sci Pub, Inc. hlm 21 - 29.

Silayoi B., O. Sahavacharin, and N. Singburadon. 1986. Induced mutation for leaf -spot disease resistence in banana. Nuclear Techniques and In vitro culture for Plant Improvement. IAEA. Vienna.

Smith, M. K., S. D. Hamill, P. W. Langdon, and K. G. Pegg. 1990. In vitro mutation breeding for the development of bananas with resistance to race 4, Fusarium wilt (Fusarium oxysporum f.sp. cubense). In: In vitro mutation breeding of banana and plantain I; Vienna 29 Mei - 2 Juni 1989. Vienna IAEA. p : 66 78.

Smith, E. D., T. B. Brenneman, and B. G. Mullinix. 1996. Interaction of five peanut genotypes with 10 isolates of
Sclerotium rolfsii. Phytopathol 84 : 1101

Suprasanna, P., M. Sidha, and T. R. Ganapathi. 2008. Characterization of radiation induced and tissue culture derived dwarf types in banana by using a SCAR marker. Australian Journal of Crop Science 1 (1) : 47 52.

Wiryosimin, S. 1995. Mengenal Azas Proteksi Radiasi. Institut Teknologi Bandung. Bandung. 